\title{
PROBLEM JĘZYKA UKRAIŃSKIEGO NA UKRAINIE NA TLE ANEKSJI KRYMU I WOJNY W DONBASIE
}

\author{
THE PROBLEM OF THE UKRAINIAN LANGUAGE IN \\ LIGHT OF THE ANNEXATION OF CRIMEA AND THE \\ WAR IN DONBAS
}

\begin{abstract}
The problem of the Ukrainian language in public discourse has been present since 1991, when Ukraine regained its independence. The problem is difficult, largely due to the historical past, mainly Soviet. For 26 years of independence Ukraine has not developed a unified and correct approach to solve this problem. This article is an attempt to analyze how the annexation of Crimea and the war in Donbas influenced the language problem in Ukraine. The analysis covers four main aspects: everyday life (interpersonal communication), commercial (press market, books and electronic media, advertising), formal and official (functioning of the state, judiciary and education system) and symbolic (identity).
\end{abstract}

Ke y w ord s: Ukrainian; Russian; language; Ukraine; Crimea; Donbas

\section{Streszczenie}

Problem języka ukraińskiego w dyskursie publicznym obecny jest od czasu odzyskania niepodległości przez Ukrainę. Problem jest trudny i złożony, co w znacznym stopniu jest spowodowane przeszłością historyczną, głównie radziecką. Przez 26 lat niepodległości Ukraina nie wypracowała jednolitego i właściwego podejścia do rozwiązania tego problemu. Kwestia językowa jest poważnym wyzwaniem dla państwa ukraińskiego i jednym z ważniejszych problemów ukraińskiej polityki we-

OKSANA VOYTYUK Uniwersytet w Białymstoku, Białystok E-mail: oksana.voytyuk@gmail.com http://orcid.org/0000-0001-6452-2893

CITATION: Voytyuk, O. (2019). Problem języka ukraińskiego na Ukrainie na tle aneksji Krymu i wojny w Donbasie. Sprawy Narodowościowe. Seria nowa, 2019(51). https://doi.org/10.11649/sn.1857

This work was supported by the author's own resources. No competing interests have been declared.

This is an Open Access article distributed under the terms of the Creative Commons Attribution 3.0 PL License (creativecommons.org/licenses/by/3.0/pl/), which permits redistribution, commercial and non-commercial, provided that the article is properly cited. (C) The Author(s) 2019

Publisher: Institute of Slavic Studies, Polish Academy of Sciences 
wnętrznej. Ma ona cztery podstawowe aspekty: codzienny (komunikacja międzyludzka), komercyjny (rynek prasy, książek i mediów elektronicznych, a także reklam), formalnourzędowy (funkcjonowanie państwa, zwłaszcza sądownictwa i systemu edukacji) oraz symboliczny/tożsamościowy. W artykule podjęto próbę analizy, w jaki sposób aneksja Krymu i wojna w Donbasie wpłynęły na kwestię językową na Ukrainie.

Stowa kluczowe: język ukraiński; język rosyjski; Ukraina; Krym; Donbas

\author{
SYTUACJA JĘZYKA UKRAIŃSKIEGO PO 1991 ROKU
}

$\mathrm{P}$

roblem języka ukraińskiego w dyskursie publicznym jest obecny od czasu odzyskania przez Ukrainę niepodległości. Problem jest trudny i złożony, co w znacznym stopniu jest spowodowane przeszłością historyczną, głównie radziecką. W okresie 26 lat niepodległości Ukraina nie wypracowała jednolitego i właściwego podejścia do rozwiązania tego problemu (Лесюк \& Шаповал, 2017).

Uważa się, że język całkowicie umiera w ciągu trzech pokoleń i proces ten odbywa się $w$ trzech etapach: na pierwszym etapie pojawia się bilingwizm, czyli dwujęzyczność. Przyczyn tego może być wiele - migracje, deportacje, zmiany historyczne, presja ideologiczna. $\mathrm{Na}$ tym etapie ma miejsce fonetyczna deformacja języka ojczystego, może on zostać pozbawiony takiego statusu. Na drugim etapie język ojczysty przestaje być używany w biznesie, nauce, sferze społecznej, aż do momentu, gdy przestaje się mówić w tym języku w gronie rodzinnym. Nosiciele języka ojczystego stają się mniejszością w ojczyźnie. Na trzecim etapie język ojczysty pozostaje jedynie w toponimach i powoli umiera (Лиманов, 1991, s. 3).

Kwestia językowa jest poważnym wyzwaniem dla państwa ukraińskiego i jednym z ważniejszych problemów ukraińskiej polityki wewnętrznej. Ma ona cztery podstawowe aspekty: codzienny (komunikacja międzyludzka), komercyjny (rynek prasy, książek i mediów elektronicznych, a także reklam), formalnourzęowy (funkcjonowanie państwa, zwłaszcza sądownictwa i systemu edukacji) oraz symboliczny/tożsamościowy (Olszański, 2012, s. 5).

\title{
JĘZYK UKRAIŃSKI W KOMUNIKACJI MIĘDZYLUDZKIEJ (CODZIENNY)
}

Z ostatnich badań socjologicznych wynika, że stosunek do używania zarówno języka ukraińskiego jak i rosyjskiego na Ukrainie po 2014 roku znacznie się zmienit; potwierdzają to badania socjologiczne wykonane w ukraińskich ośrodkach badań socjologicznych w latach 2014-2017. Na szczególną uwagę w tym kontekście zasługują badania Centrum Razumkowa, które zostały przeprowadzone w grudniu 2016 roku na całym terytorium Ukrainy z wyjątkiem okupowanych terenów Donbasu i Krymu. Przepytano ponad 10,7 tys. respondentów. W 2016 roku ponad 60\% obywateli Ukrainy uznawało język ukraiński za ojczysty, $15 \%$ - język rosyjski, 22\% respondentów uważało za ojczysty dwa języki - rosyjski i ukraiński, 2\% - inne języki. W porównaniu z 2006 rokiem, kiedy Centrum Razumkowa robiło podobne badania, sytuacja w 2016 roku wygląda nieco lepiej, gdyż w tamtym 
okresie język ukraiński za ojczysty uważało jedynie 52\% respondentów, 31\% - za język ojczysty uważało rosyjski, 16\% - obydwa języki uważało za ojczyste, a inne języki stanowity 1\% (Wykres 1).

Wykres 1. Uznawanie języka ukraińskiego za ojczysty (w \%)

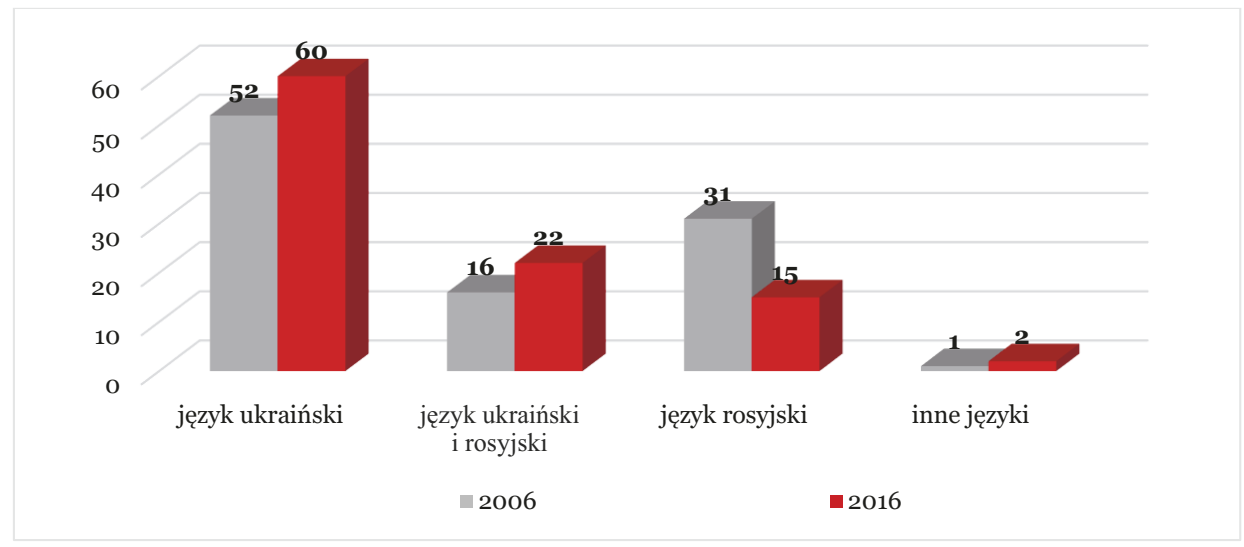

Źródło: opracowanie własne na podstawie danych Centrum Razumkowa („Спільна ідентичність громадян України", 2007, s. 4).

Jak wynika z Wykresu 1, przez ostatnie 10 lat liczba obywateli Ukrainy, którzy uznają język ukraiński za ojczysty wzrosła o 8\%, jednocześnie także wzrosła o 6\% liczba osób, które w równej mierze za ojczysty uznają język ukraiński i rosyjski. Z kolei o 16\% zmalała liczba osób, które za język ojczysty uznają rosyjski. Wydaje się, że główna przyczynazmniejszenia liczby osób, które język rosyjski uważają za ojczysty związana jest przede wszystkim z aneksją Krymu w 2014 roku, gdzie dominowała ludność rosyjskojęzyczna, oraz z wojną w Donbasie. W chwili obecnej trudno jest powiedzieć, jaki jest odsetek obywateli Ukrainy, którzy zmienili nie tylko zdanie na temat języka, ale również zaczęli używać języka ukraińskiego na co dzień. Faktem pozostaje to, że przez 26 lat niepodległości Ukrainy liczba osób uznających język ukraiński za ojczysty, według rozmaitych badań socjologicznych, nigdy nie przekroczyła $65 \%$.

Wykresy 2 i 3 wskazują, że w kontekście geograficznym w 2016 roku 92,6\% mieszkańców zachodnich regionów Ukrainy posługiwało się językiem ukraińskim, 78,2\% - w centrum, 35,3\% - na wschodzie, 37,4\% - na południu oraz 19,9\% w Donbasie. W porównaniu z 2006 rokiem liczba osób uznających język ukraiński za ojczysty wzrosła we wszystkich regionach. Jednocześnie w 2016 roku w porównaniu do 2006 roku wzrosła liczba osób, które uznają obydwa języki za ojczyste, oprócz zachodu, gdzie ta liczba zmniejszyła się z 3,2\% (2006) do 2,9\% (2016).

Zmalała liczba osób, które uważają język rosyjski za ojczysty we wszystkich regionach oraz wzrosła liczba osób uznających inne języki za ojczyste na wschodzie i południu, zmalała na zachodzie i została bez zmian w centrum kraju. Wzrost popularności języka ukraińskiego na wschodzie i południu kraju można po części wytłumaczyć następująco: wojna w Donbasie znacznie podzieliła społeczeństwo objętych konfliktem obwodów donieckiego i ługańskiego na tych, którzy wspierają politykę Ukrainy, i tych, którzy wspierają samozwańcze republiki i politykę Rosji. Jak zmieniało się podejście do wydarzeń w Don- 
Wykres 2. Uznawanie języka ukraińskiego za język rodzimy (kontekst regionalny) w 2006 roku (w \%)

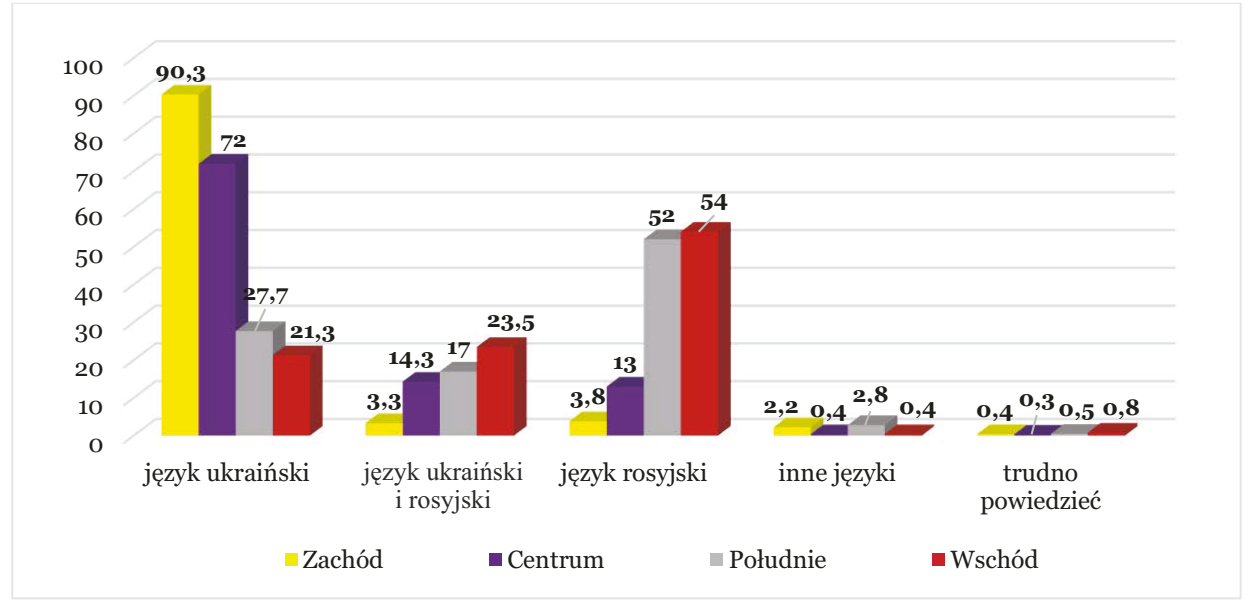

Źr ó dło: „Ідентичність громадян України в нових умовах", 2016, s. 33; „Спільна ідентичність громадян України", 2007, s. 4.

Zachód - obwody: zakarpacki, wołyński, rówieński, Iwowski, iwano-frankowski, tarnopolski, czerniowiecki, chmielnicki; Centrum - obwody: żytomierski, winnicki, bachmutski (kirowogradzki): czerkaski, połtawski, sumski, czernihowski, kijowski i miasto Kijów; Południe - obwody: odeski, chersoński, zaporoski, dnieprowski; Wschód - obwody: charkowski, doniecki, tugański.

Wykres 3. Uznawanie języka ukraińskiego za język rodzimy (kontekst regionalny) w 2016 roku (w \%)

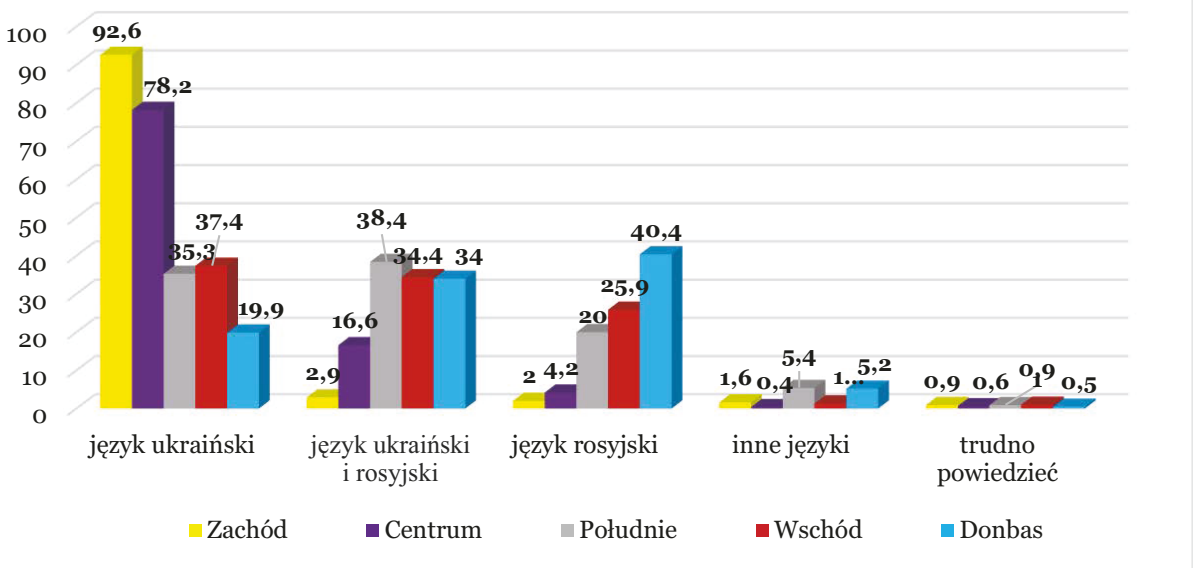

Źr ó d † : „Ідентичність громадян України в нових умовах”, 2016, s. 33; „Спільна ідентичність громадян України", 2007, s. 4. 
basie, można przeanalizować na podstawie opinii ludności z terenów, które wcześniej były pod kontrolą republik samozwańczych, ale po pewnym czasie zostały zwolnione siłami armii ukraińskiej, np. miasto Słowiańsk. Ludność, która ma nastawienie proukraińskie, przez używanie języka ukraińskiego w życiu codziennym próbuje wykazać swą lojalność i wsparcie dla Ukrainy, jednak to nie znaczy, że ludność rosyjskojęzyczna wspiera agresję w Donbasie. Jak wynika z relacji wielu wolontariuszy, którzy udzielają aktywnej pomocy ludności i wojskowym na linii rozgraniczenia, liczba rosyjskojęzycznych patriotów Ukrainy mniej więcej dorównuje liczbie ukraińskojęzycznych patriotów Ukrainy, więc twierdzenie, że osoba, która posługuje się w życiu codziennym językiem rosyjskim jest zdrajcą, nie jest właściwe. Bardzo dobry przykład dla całego społeczeństwa ukraińskiego dają Tatarzy Krymscy', którzy z różnych przyczyn (głównie są to prześladowania, areszty, szantaż, zastraszanie) zmuszeni byli zostawić półwysep Krymski po aneksji i przenieść się do kontynentalnej części Ukrainy. Większość Tatarów Krymskich nigdy nie uczyła się i nie rozmawiała w języku ukraińskim, ale po aneksji Krymu, aby pokazać wsparcie dla Ukrainy i udowodnić swoją lojalność dla państwa ukraińskiego, zaczęli rozmawiać w języku ukraińskim. Szczególnie dobry przykład dla naśladowania podają, tzw. krymskotatarskie celebrities oraz osoby publiczne - przewodniczący Medżlisu Tatarów Krymskich Refat Czubarow, piosenkarka Jamala, reżyser Ahtem Seitablajew, dziennikarze krymskotatarskiego kanału telewizyjnego ATR i wiele innych. W bardzo krótkim czasie wspomniane osoby nauczyły się języka ukraińskiego i w swoich wystąpieniach publicznych posługują się głównie tym językiem, podkreślając, że jest to pewnego rodzaju ich sposób na walkę z władzami okupacyjnymi półwyspu. Zwiększenie udziału języka ukraińskiego na południu można wyjaśnić również tym, że Tatarzy Krymscy, którzy opuścili Krym, zamieszkują głównie przygraniczne tereny z półwyspem, głównie obwód chersoński, ponadto, część ich wyjechała do zachodnich obwodów Ukrainy, głównie do Lwowa, a część wyjechała do stolicy - Kijowa.

Ciekawie również wygląda sytuacja z posługiwaniem się językiem ukraińskim w domu. Zgodnie z danymi statystycznymi za ostatnie 10 lat o 3,8\% wzrosła liczba osób posługujących się językiem ukraińskim, z kolei liczba osób posługujących się językiem rosyjskim zmalała o 13,9\%. Ponadto, o 10\% wzrosła liczba osób bilingwalnych, które na co dzień posługują się językiem rosyjskim i ukraińskim w równej mierze (Wykresy 4 i 5).

Jak wynika z Wykresów 4 i 5, poza domem językiem ukraińskim posługuje się o 4,2\% mniej osób, niż zadeklarowano w domu. Poza tym, o 4,2\% wzrosła liczba osób, które poza domem posługują się zarówno rosyjskim jak i ukraińskim, o 0,3\% wzrosła liczba osób posługujących się głównie językiem rosyjskim poza domem.

Jak wskazują dane statystyczne z Wykresów 6 i 7, poza domem odsetek osób używających języka ukraińskiego maleje, w zależności od regionu, a języka rosyjskiego rośnie głównie w centrum, na wschodzie i południu. Częstotliwość używania języka ukraińskiego w domu wzrosła, jak i częstotliwość używania obydwu języków, z kolei używanie języka rosyjskiego zmalało. Nieco gorzej wygląda sytuacja poza domem, wciąż w wielu regionach język rosyjski jest sposobem codziennej komunikacji.

1 Tatarzy Krymscy i Tatarzy są odrębnymi narodami, dlatego pisanie dwuwyrazowej nazwy narodu wielkimi literami jest uzasadnione. Napisanie wyrazu w formie „Tatarzy krymscy” oznacza, np., że Tatarzy Krymscy i Tatarzy kazańscy są jednym narodem, tyle że zamieszkują inne regiony, co nie jest zgodne z rzeczywistością. Dokładniej o tym w: Voytyuk, 2017. 
Wykres 4. Jakim językiem posługujesz się w domu? (w \%)

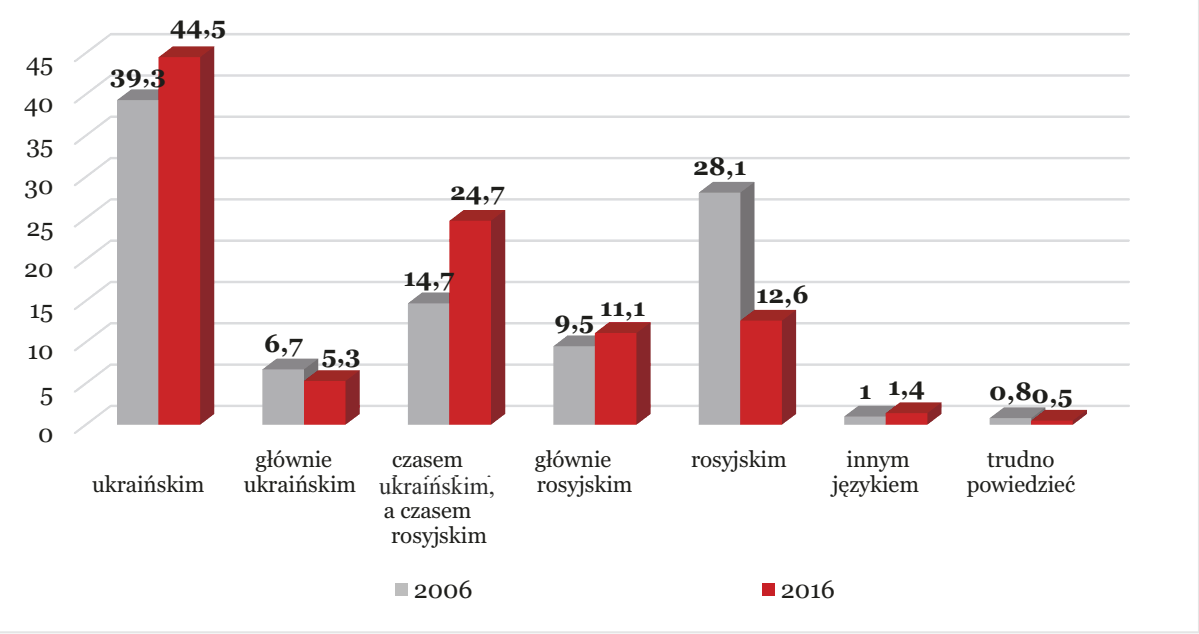

Źr ó d to: „Ідентичність громадян України в нових умовах", 2016, s. 33.

Wykres 5. Jakim językiem posługujesz się poza domem? (2016) (w \%)

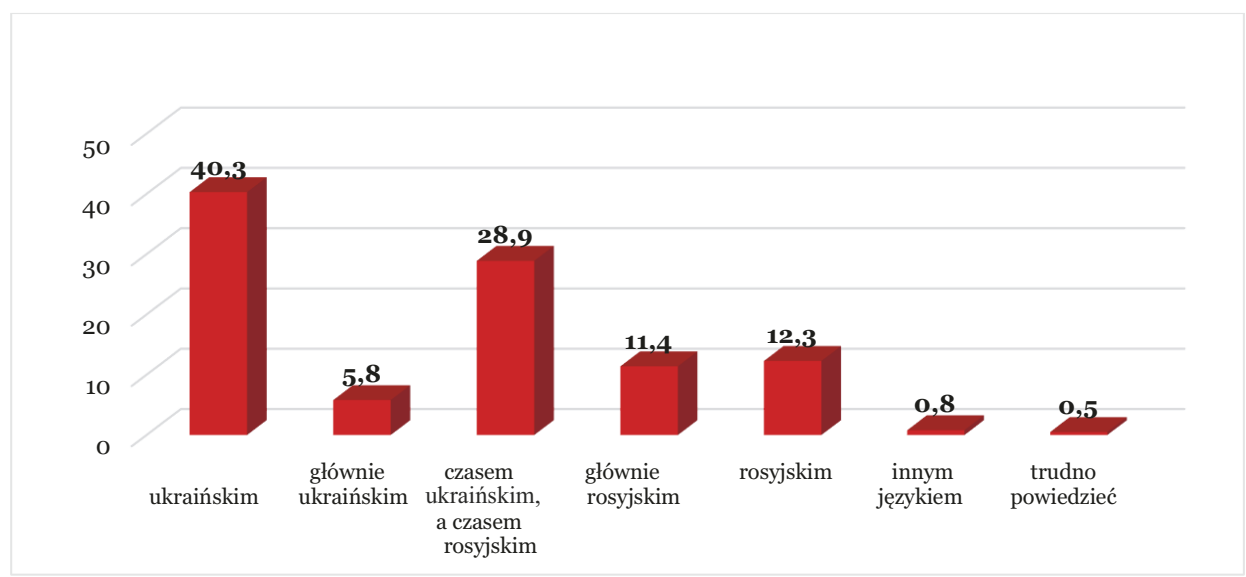

Źr ó d †o: „Ідентичність громадян України в нових умовах", 2016, s. 33.

Jak wynika z Wykresu 8, jedynie 43,2\% respondentów powiedziało, że w ich otoczeniu bardziej prestiżowo jest rozmawiać w języku ukraińskim, 21,5\% za bardziej prestiżowy język komunikacji w ich otoczeniu uznało rosyjski. Wykres wskazuje także na to, że słaba jest komunikacja w języku angielskim - jedynie 1,1\%, a 29\% respondentów odpowiedziało, że w ich otoczeniu obojętne jest, w jakim języku rozmawiają. W kontekście regionalnym język ukraiński jest popularny w komunikacji na zachodzie kraju - 88\%, w centrum popularność komunikacji w języku ukraińskim stanowi 51\%, na południu 16\%, na wscho- 
Wykres 6. Jakim językiem posługujesz się w domu? (kontekst regionalny), 2016 (w \%)

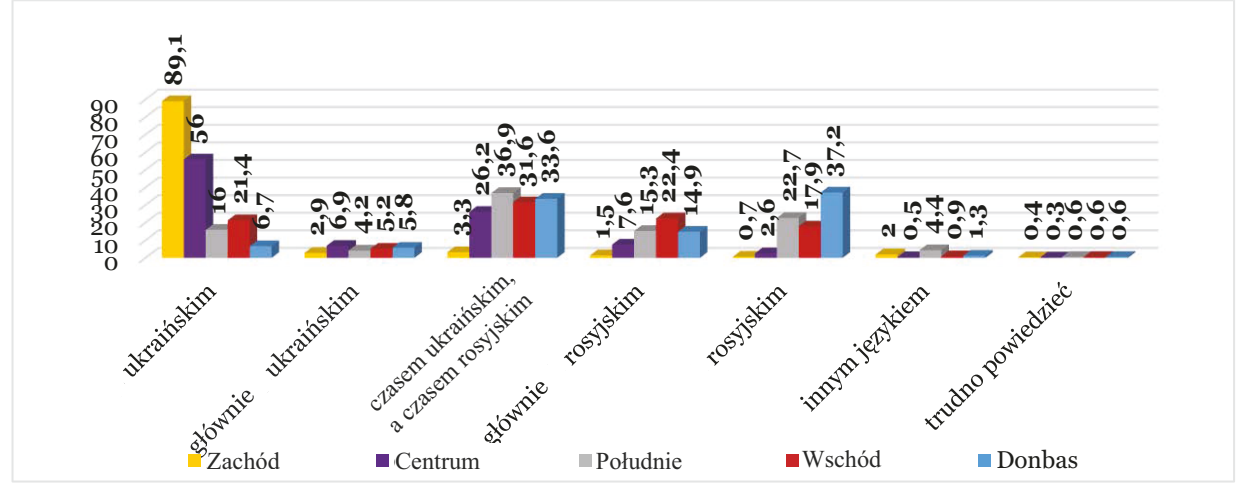

Źr ó d to: „Ідентичність громадян України в нових умовах", 2016, s. 33.

Wykres 7. Jakim językiem posługujesz się poza domem? (kontekst regionalny), 2016 (w \%)

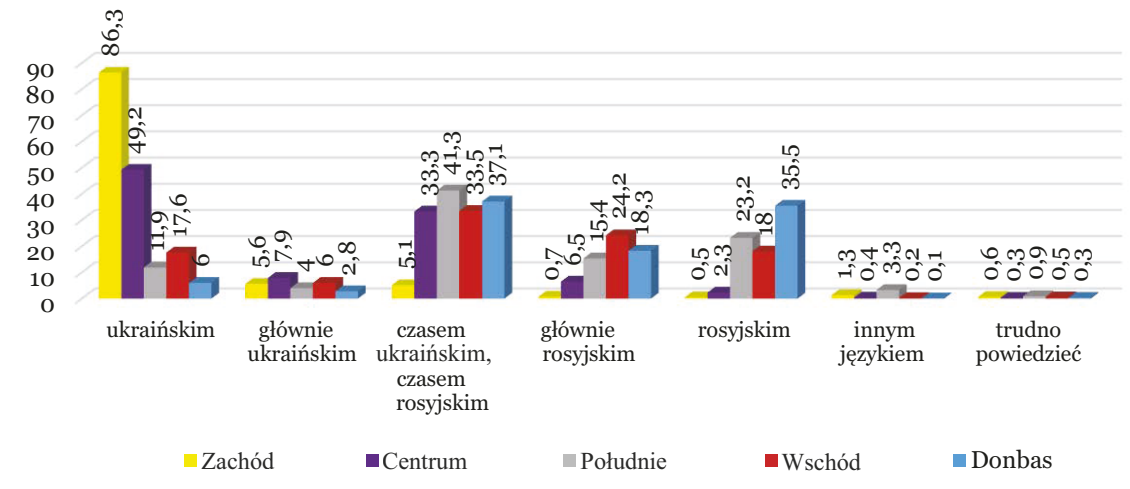

Źr ó d † о: „Ідентичність громадян України в нових умовах", 2016, s. 33.

dzie $21 \%$, a w Donbasie - 11\%. Język rosyjski za prestiżowy sposób komunikacji na zachodzie uważa jedynie 2\% mieszkańców, w centrum 12\%, na południu 29\%, na wschodzie $34 \%$ oraz 50\% mieszkańców Donbasu uważa rosyjski za prestiżowy. Jak wynika z danych statystycznych, najwięcej wagi do języka komunikacji przywiązują mieszkańcy zachodu, gdzie liczba osób, którym obojętne jest to, w jakim języku rozmawiają, stanowi jedynie 6,5\%, z kolei w centrum, na wschodzie i Donbasie takich osób jest znacznie więcej, odpowiednio 32\%, 38\% i 30\%. Najwięcej osób, którym obojętnie jest w jakim języku rozmawiają, jest na południu - 47\%. Z badań wynika, że język ukraiński jest prestiżowy na zachodzie kraju, w Donbasie językiem prestiżu jest język rosyjski, z kolei na południu i na wschodzie dla wielu osób ta kwestia jest nieaktualna (Wykres 9). Poważny problem w kontekście używania języka ukraińskiego występuje w stolicy, dominująca większość 
Wykres 8. W jakim języku bardziej prestiżowo rozmawiać w towarzystwie przyjaciół i kolegów z pracy czy uczelni? (2016) ( w \%)

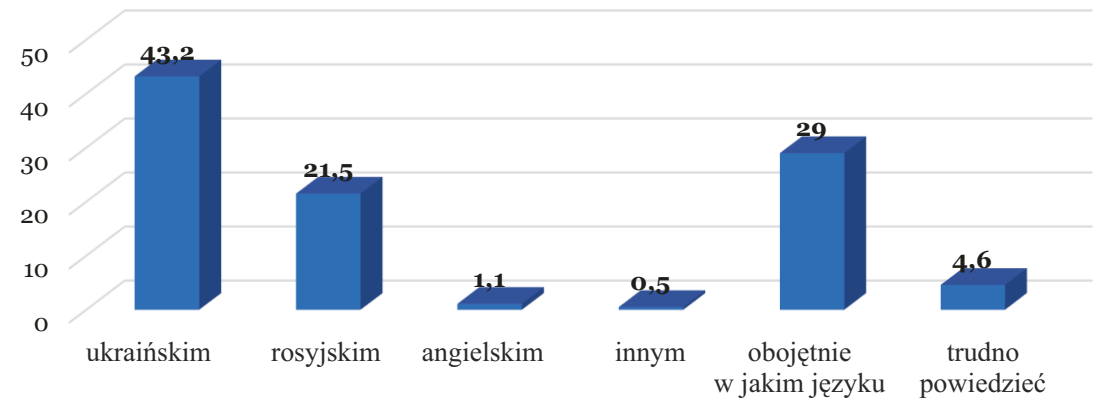

Źr ó d †o: „Ідентичність громадян України в нових умовах", 2016, s. 33.

Wykres 9. W jakim języku bardziej prestiżowo rozmawiać w towarzystwie przyjaciół i kolegów z pracy czy uczelni? (kontekst regionalny) (2016) (w \%)

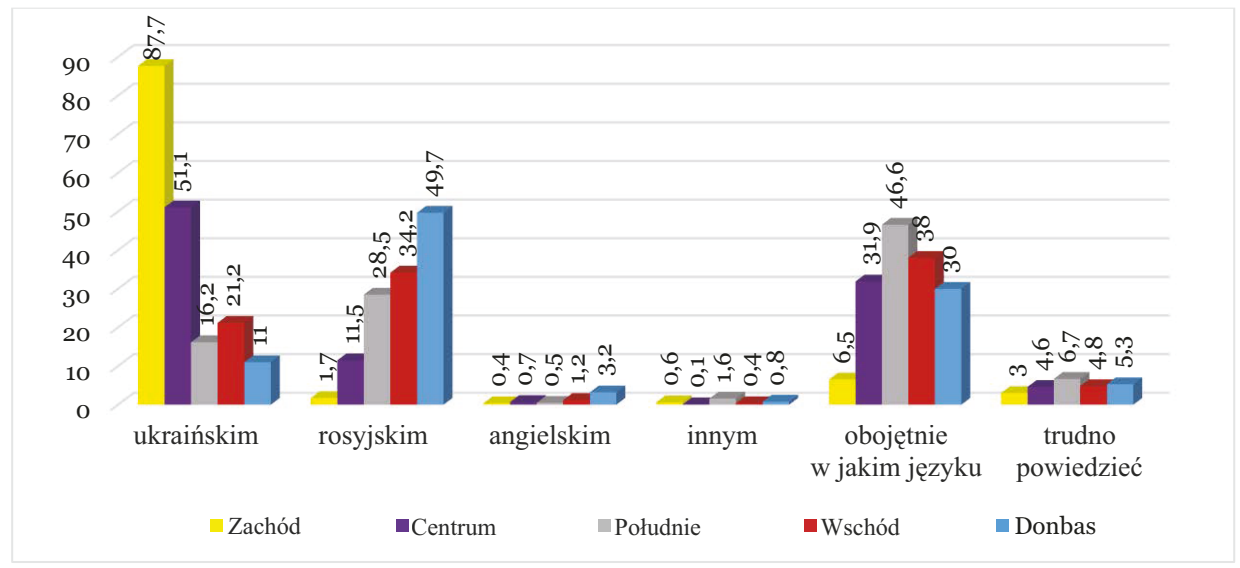

Źr ó d †o: „Ідентичність громадян України в нових умовах”, 2016, s. 33. 
społeczeństwa posługuje się tam językiem rosyjskim, nawet osoby ukraińskojęzyczne, które przyjeżdżają do Kijowa, po pewnym czasie przechodzą na rosyjski. Wynika to głównie z przeszłości historycznej, w okresie przedwojennym i powojennym język ukraiński uważano bowiem za język wsi i posługiwanie się tym językiem świadczyło o pochodzeniu ze wsi. Sytuacja w stolicy zaczęła powoli się zmieniać po rewolucji godności, coraz więcej osób stara się używać w komunikacji codziennej języka ukraińskiego. Często zdarzają się sytuacje, kiedy ludzie wręcz wymagają od osób rosyjskojęzycznych, by zwracać się do nich w języku ukraińskim, szczególnie w miejscach publicznych - sklepach, supermarketach, restauracjach.

Wydaje się być problemem stopień posługiwania się językiem ukraińskim jedynie 65\% pytanych swobodnie posługuje się tym językiem. 28\% uważa, że stopień ich znajomości języka ukraińskiego jest wystarczający dla codziennej komunikacji, jednak nie wystarcza w dyskusji ze specjalistyczną tematyką. 4,4\% ankietowanych ma problem z mówieniem i rozumieniem w języku ukraińskim. 0,4\% całkowicie nie rozumieją ukraińskiego. Poziom języka ukraińskiego znacznie się różni w zależności od regionu. Swobodnie rozmawia w języku ukraińskim 94\% mieszkańców zachodu, 72\% - mieszkańców centrum, 52\% mieszkańców wschodu, 49\% - na południu, 39\% w Donbasie. We wszystkich regionach przeważająca większość mieszkańców (99-81\%) językiem ukraińskim posługuje się swobodnie bądź na poziomie wystarczającym.

\section{JĘZYK UKRAIŃSKI NA SZCZEBLU KOMERCYJNYM}

Wydawanie książek na Ukrainie do niedawna miało negatywną tendencję. Wynikało to głównie z tego, że druk książek był nierentowny, a poza tym ogromną konkurencję na ukraińskim rynku stanowiły książki z Rosji, wydawane w języku rosyjskim. Na książki w języku ukraińskim zapotrzebowanie było niewielkie. W 2014 roku książki w języku ukraińskim stanowiły 54,9\% ogólnej liczby wydanych w Ukrainie książek. Jednak już w 2015 roku liczba książek wydanych w języku ukraińskim stanowiła 65,2\%, a od 1 stycznia do 20 października 2016 roku - 64,6\%. Spadek drukowanej produkcji w języku ukraińskim jest związany z kwestiami finansowymi oraz z dużą konkurencją książek w języku rosyjskim na ukraińskim rynku. Znacznie gorzej wygląda sytuacja czasopism, odsetek czasopism wydawanych w języku ukraińskim za ostatnie trzy lata nieco wzrósł z 9,9\% w 2014 roku do 24,4\% w 2016 roku, ale wciąż pozostaje na niskim poziomie w stosunku do czasopism wydawanych w języku rosyjskim. Czasopisma w języku rosyjskim w 2014 roku stanowity 85,6\% wszystkich wydawanych czasopism, a w 2016 roku - 62,6\% (Wykres 10).

Podobnie jak z czasopismami wygląda sytuacja z gazetami, udział gazet wydawanych w języku rosyjskim wciąż pozostaje wysoki; w 2016 roku stanowił on 61,5\%, z kolei udział gazet w języku ukraińskim za ostatnie trzy lata wzróst jedynie o 5\% z 29,5\% w 2014 roku do 34,1\% w 2016 roku („Російська мова”, 2016).

Bez względu na to, że sytuacja książki na Ukrainie wciąż pozostaje trudna, odnotowuje się pozytywną tendencję. Wzrost liczby wydawanych książek rozpoczął się po rozpętaniu wojny w Donbasie, wtedy to większość obywateli Ukrainy zaczęła świadomie rezygnować z rosyjskojęzycznych książek. Jeśli do 2014 roku rosyjska literatura stanowiła 80\%, to w 2016 roku stanowi ona 40-60\% i odsetek ten spada ("Огляд ринку", 2017). 
Wykres 10. Książki, periodyki i czasopisma i gazety wydawane na Ukrainie w latach 2014-2016 (w \%)
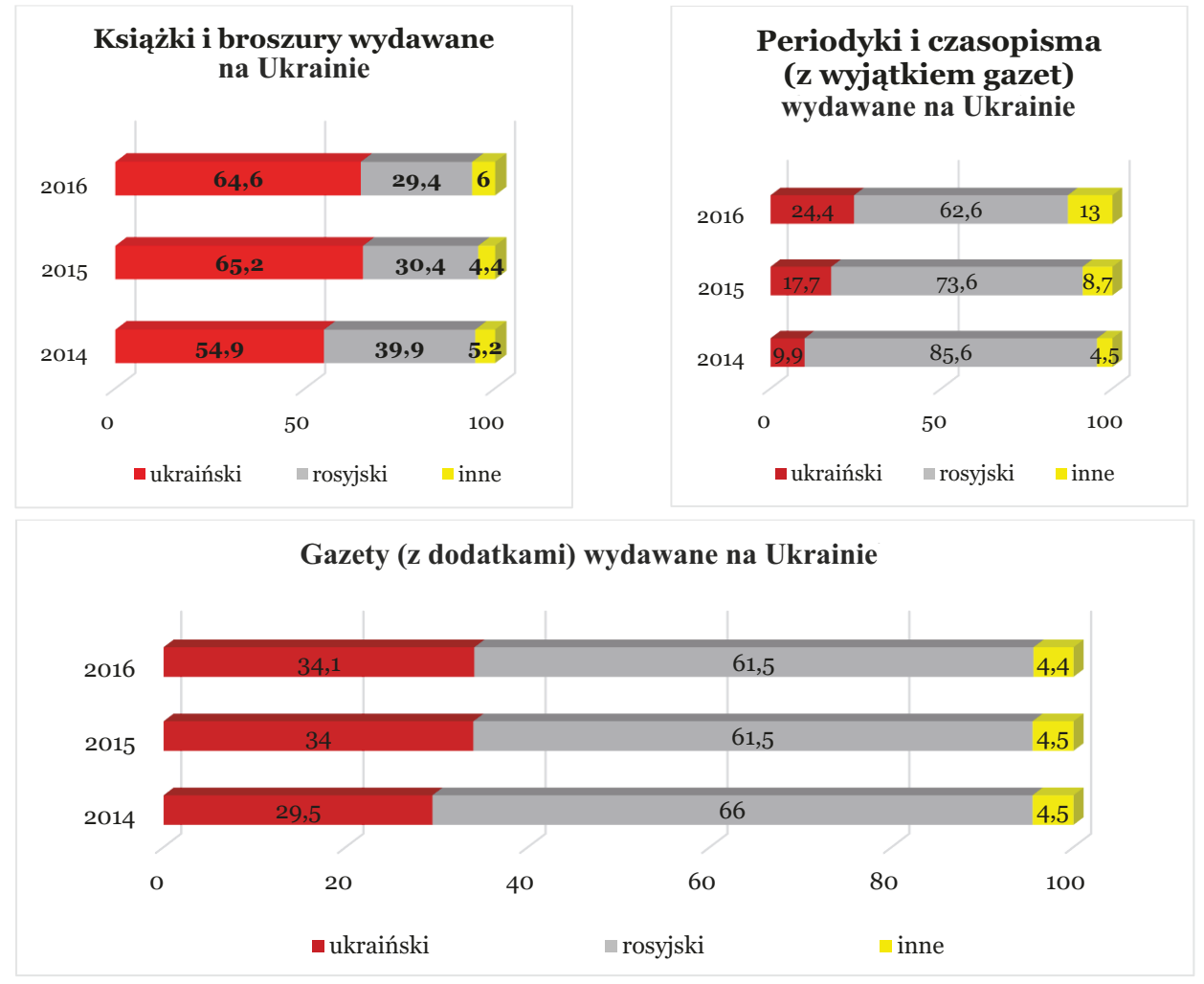

Źr ó dł о: „Огляд ринку”, 2017; „Російська мова”, 2016.

Według publicznego monitoringu udział języka ukraińskiego w czołowych kanałach telewizyjnych waha się w granicach 30\%, programy rosyjskojęzyczne stanowią 35-40\%, resztę stanowią dwujęzyczne programy, z reguły $w$ takich programach dominuje język rosyjski (Wykres 11).

Jak wynika z Wykresu 11, w ciągu ostatnich trzech lat udział języka ukraińskiego w telewizji prawie się nie zmienit i wynosił ok. 30\%. Wzrósł udział programów dwujęzycznych z 7,9\% w 2013 roku do 35\% w 2016 roku. Udziat języka rosyjskiego w latach 2013-2016 zmniejszył się z 50,3\% do 34,4\%

Jak wynika z Wykresu 12, udział języka ukraińskiego na ukraińskich kanałach różni się w znacznym stopniu. Ranking kanałów powstał na podstawie dwudniowego monitoringu sieci nadawczych. Język rosyjski dominuje na kanałach Inter i Ukraina oraz na STB, Enter Film. Z kolei język ukraiński dominuje na 1+1, Nowym, 112. Prawie 100\% język ukraiński stanowi na 5 kanale, ERA, Pierwszy oraz Espreso. Znacznie gorzej wygląda sytuacja na regionalnych kanałach telewizyjnych, im dalej na południe i wschód, tym rzadziej można tam usłyszeć język ukraiński. Ponadto, w regionach znajdujących na linii rozgraniczenia z Krymem i Donbasem sygnał ukraińskich stacji telewizyjnych i radiowych często jest celowo zagłuszany. 
Wykres 11. Język czołowych kanałów telewizyjnych, udział czasu antenowego (w \%) (dni robocze w godz. 18-22, niedziela w godz. 12-16)

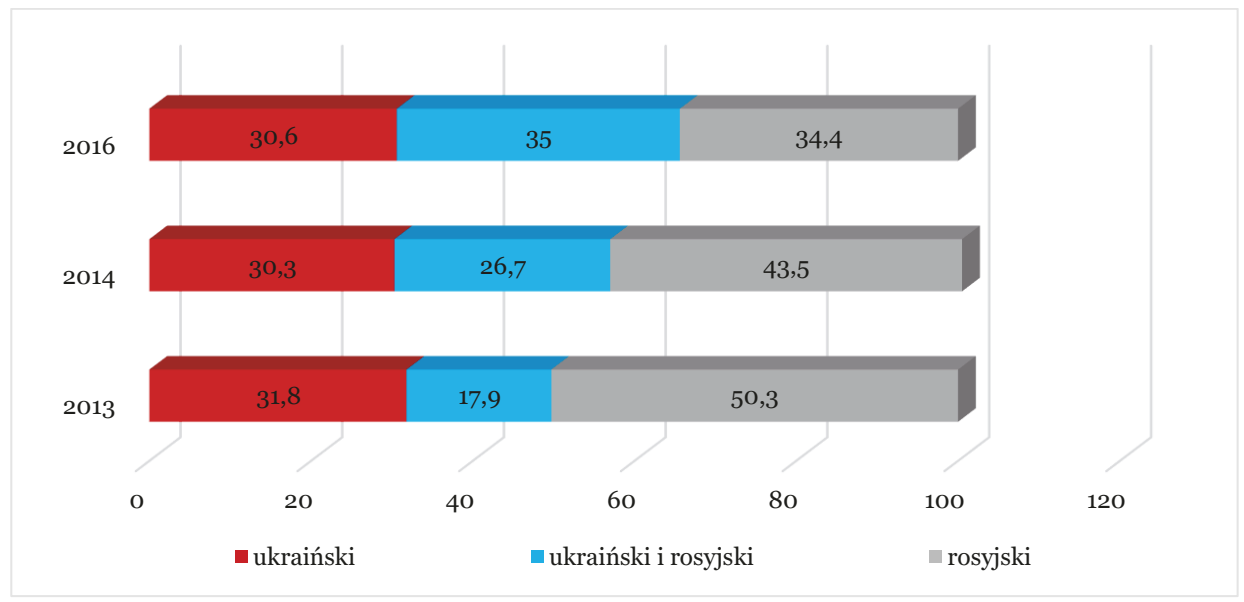

Żródto: "Miф", 2017.

Zgodnie z danymi statystycznymi z Tabeli 1, oglądalność zachodnich filmów w języku ukraińskim wzrasta bardzo po woli, z kolei oglądalność w języku rosyjskim maleje. Ciekawy jest także fakt, że wzrasta oglądalność filmów rosyjskojęzycznych z ukraińskim dubbingiem lub napisami i maleje oglądalność po rosyjsku. Podobnie wygląda sytuacja w kinach. Z Tabeli 1 wynika, że w ciągu ostatnich trzech lat odnotowuje się stopniowe przejście od filmów i programów rosyjskojęzycznych do ukraińskojęzycznych. Język ukraiński jest bardziej akceptowalny dla produktów zachodnich, które tak czy inaczej należy tłumaczyć. Nie-

Tabela 1. Preferencje językowe co do oglądania zachodnich i rosyjskich filmów i programów telewizyjnych (w \%)

\begin{tabular}{|l|l|c|c|c|}
\hline \multicolumn{1}{|c|}{ Filmy i programy } & \multicolumn{1}{|c|}{ Preferencje } & 2012 & 2014 & 2017 \\
\hline \multirow{4}{*}{$\begin{array}{l}\text { W telewizji, filmy } \\
\text { zachodnie, seriale }\end{array}$} & w języku ukraińskim & 38,5 & 42,4 & 45,9 \\
\cline { 2 - 5 } & w języku rosyjskim & 50 & 35,8 & 37,1 \\
\cline { 2 - 5 } & w ogóle nie oglądam & 5 & 8,7 & 9,3 \\
\cline { 2 - 5 } & trudno powiedzieć & 6,5 & 13,1 & 7,8 \\
\hline \multirow{4}{*}{$\begin{array}{l}\text { W telewizji, rosyjskie } \\
\text { filmy rosyjskie, seriale }\end{array}$} & w języku ukraińskim & 20 & 25,3 & 30 \\
\cline { 2 - 5 } & w języku rosyjskim & 70,1 & 57 & 52,5 \\
\cline { 2 - 5 } & w ogóle nie oglądam & 4,1 & 7,2 & 9,5 \\
\cline { 2 - 5 } & trudno powiedzieć & 5,8 & 10,5 & 8,1 \\
\hline \multirow{4}{*}{$\begin{array}{l}\text { W kinach, filmy } \\
\text { zachodnie }\end{array}$} & w języku ukraińskim & 21,8 & 30,8 & 30 \\
\cline { 2 - 5 } & w języku rosyjskim & 35 & 31,1 & 28,5 \\
\cline { 2 - 5 } & w ogóle nie oglądam & 36,6 & 27,9 & 35 \\
\cline { 2 - 5 } & trudno powiedzieć & 6,7 & 10,3 & 6,5 \\
\hline
\end{tabular}

Źr ódło: „В усіх типах медій”, 2017, 
Wykres 12. Udział języka ukraińskiego na antenie ogólnokrajowych kanałów telewizyjnych (w \%)

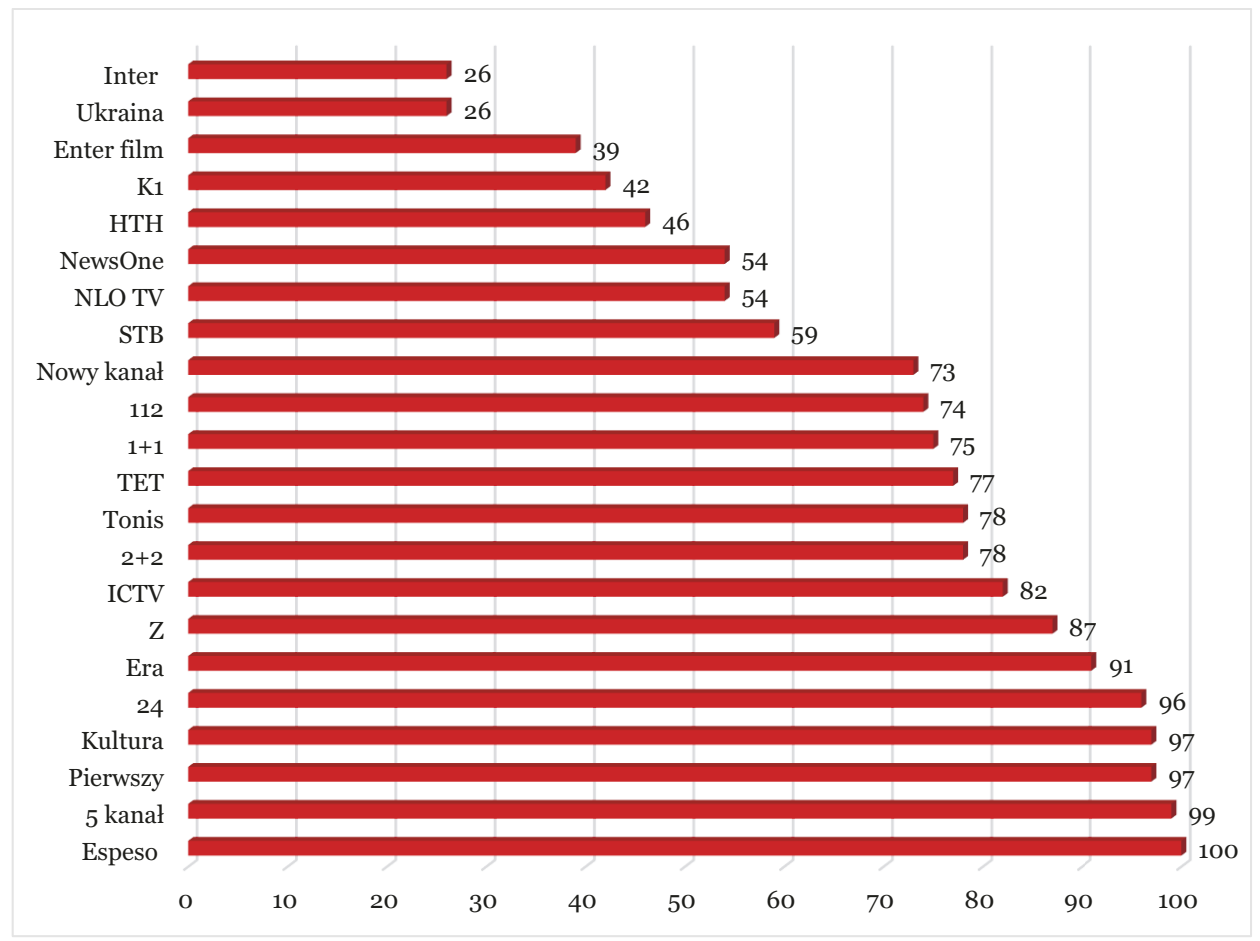

Źródto: „Miф”, 2017.

Wykres 13. Udział ukraińskich piosenek na najpopularniejszych stacjach radiowych (w godz. 7-14) według stanu na 25.10.2016 roku (w \%)

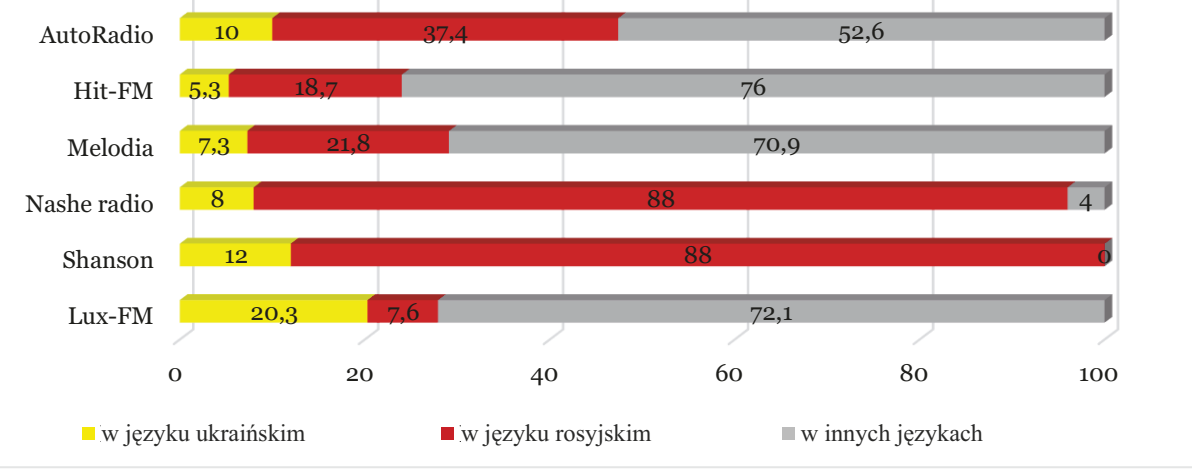

Źród to: „Становище”, 2016, s. 29. 
co inaczej wygląda sytuacja z programami i filmami rosyjskojęzycznymi, 1/3 ukraińskojęzycznych respondentów preferuje oglądać je w języku rosyjskim, bez tłumaczenia, z kolei ludność rosyjskojęzyczna preferuje takie filmy i programy w 100\% („В усіх типах медій”, 2017). Tłumaczenie rosyjskojęzycznych filmów na język ukraiński wydaje się czymś nieco absurdalnym i opinie społeczne na ten temat są podzielone. Podobnie jak w przypadku oglądalności filmów rosyjskich, które często były produkowanie wspólnie z Ukrainą bądź grali w nich ukraińscy aktorzy. Obecnie na Ukrainie obowiązuje zakaz emitowania rosyjskojęzycznych filmów, które zawierają elementy propagandy, głównie to filmy dotyczące tematyki wojskowej, związane z II wojną światową bądź znanymi postaciami tego okresu, oraz wydane po 2014 roku. Ponadto, zakaz obejmuje filmy, które zawierają elementy przemocy, gloryfikację działań państwa-agresora, czyli Rosji („В Україні”, 2016; „Про внесення", 2016). Niestety sytuacja może nabrać formy kuriozalnej, kiedy w walce z propagandą rosyjską, lista filmów zakazanych do oglądania na Ukrainie wypełni się serialami, które nie mają kontekstu propagandowego, ale aktorzy, którzy zagrali w tych filmach, odwiedzili Krym po jego aneksji, w sposób zakazany - czyli poprzez bezpośrednie połączenie powietrzne Moskwa-Symferopol, bądź wspierają aneksję Krymu². Przykładem są gorące dyskusje dotyczące rosyjsko-ukraińskiego serialu komediowego "Swaty". Aktorzy, którzy zagrali w serialu, mają zakaz wjazdu na Ukrainę, gdyż wsparli aneksję Krymu, jeśli Służba Bezpieczeństwa Ukrainy uzna, że te osoby zagrażają bezpieczeństwu państwa, serial może zostać zakazany („Свати", 2017).

Według danych statystycznych udział ukraińskojęzycznych programów w ostatnich trzech latach prawie się nie zmienił i stanowi około 30\%. Jednak odnotowuje się stałą tendencję wzrostu liczby dwujęzycznych programów. W 2013 roku liczba takich programów stanowiła 18\%, a w 2016 - 35\%, przy czym dominującym językiem w programach dwujęzycznych jest rosyjski. Liczba rosyjskojęzycznych programów nieco się zmniejszyła się i w 2016 roku stanowiła 34,4\%. Pomimo zmiany proporcji między całkowicie i częściowo rosyjskojęzycznymi programami, ogólny udział tych programów pozostaje na poziomie ok. 70\%. Język rosyjski nadal dominuje w telewizji narodowej. Telewizja, podobnie jak wiele lat z rzędu, pozostaje jednym z kluczowych narzędzi rusyfikacji, dyktowania języka rosyjskiego odbiorcom wszystkich pokoleń, począwszy od dzieci („В усіх типах медій", 2017).

Ze względu na dużą liczbę stacji radiowych trudno obliczyć parytet pomiędzy językiem ukraińskim a rosyjskim. Dane oficjalne dotyczące państwowych stacji radiowych potwierdzają, że tam dominuje język ukraiński. Jednak czas transmisji jest niewielki. Na stacjach FM dominują rosyjskojęzyczne piosenki i programy. W ciągu ostatnich trzech lat odnotowuje się wzrost liczby audycji muzycznych w języku ukraińskim. Podobną sytuację odnotowuje się na telewizyjnych kanałach muzycznych (Мовний баланс України, 2017).

Z Wykresu 13 wynika, że w 2016 roku w ukraińskich stacjach radiowych dominowały piosenki w języku rosyjskim. Najwięcej rosyjskich piosenek można było usłyszeć w radiu Shanson i Naszym Radiu, najmniej na Lux-FM, z kolei piosenek w języku ukraińskim najwięcej można było usłyszeć na Lux-FM. Z monitoringu wynika, że z 390 (100\%) piosenek, które były transmitowane w godzinach 7-14 na przedstawionych stacjach radiowych jedynie 39 było w języku ukraińskim, co stanowiło 10\%. W języku rosyjskim było 146 piosenek (37,6\%), reszta to piosenki w innych językach - 205 piosenek (52,6\%). Mimo że

\section{-....}

Zgodnie z wymogami ukraińskiego ustawodawstwa, terytorium czasowo okupowane, nie naruszając ustawodawstwa Ukrainy, można odwiedzić tylko drogą lądową, przez punkty przejścia - Czongar, Czapłynka i Kałanczak. 
liczba ukraińskich piosenek jest wciąż niewielka, jest ro najwyższy wskaźnik za ostatnie 7 lat (w latach 2011-2015 wahał się on w granicach 3-5\%). Wzrost treści ukraińskich wyjaśnia się wprowadzeniem w życie ustawy z 16 czerwca 2016 roku „O zmianie niektórych ustaw Ukrainy w sprawie udziału utworów muzycznych w języku państwowym w programach organizacji telewizyjnych i radiowych", zgodnie z którą w godzinach od 7 do 14 stacje radiowe zostały zobowiązane transmitować nie mniej jak 25\% w języku ukraińskim („Про внесення", 2016).

Ważne znaczenie w dzisiejszych ukraińskich realiach mają nie tylko treści muzyczne, ale również inne programy. Na przykład, radio Hit-FM wprowadziło „Wykres dla żołnierza". Celem programu jest zachęcanie dzieci oraz ich rodziców do tworzenia rysunków, które na front będą przekazywać wolontariusze („GFK Ukraine”, 2017). Z badań Stanisława Swidłowa, "Stan języka ukraińskiego w ukraińskim segmencie internetu”, wynika, że w ukraińskim internecie dominuje język rosyjski. Według rankingu 1000 najpopularniejszych stron internetowych ukraińskojęzyczne strony stanowią 11\%, dwujęzyczne $-22,2 \%$, a rosyjskojęzyczne $-66,8 \%$.

Wykres 14. Stan języka ukraińskiego w ukraińskim segmencie internetu (w \%)

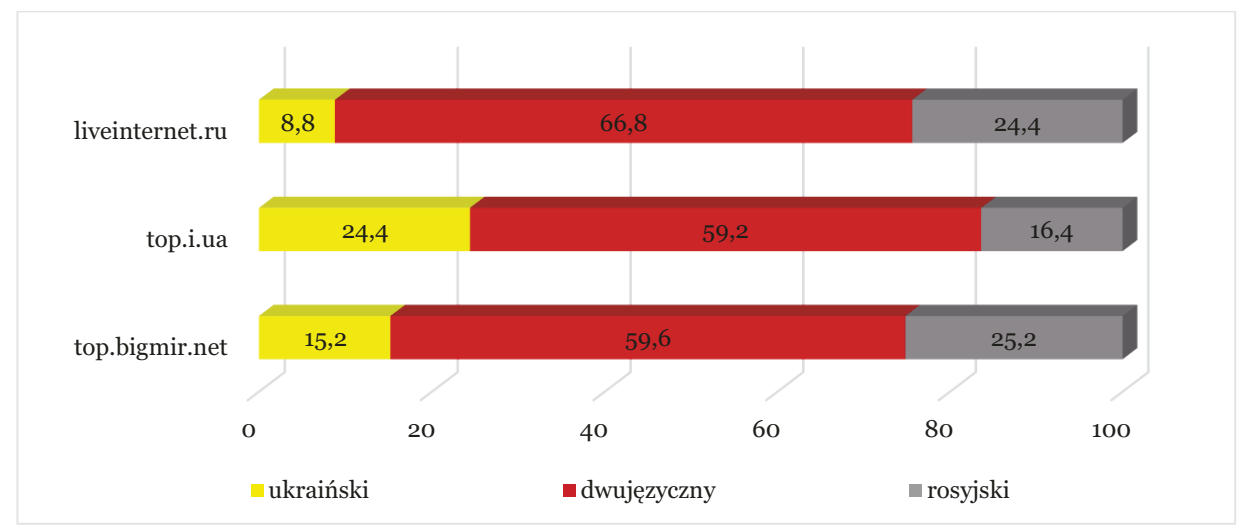

Źr ó dło: „В усіх типах медій”, 2017.

Jak wynika z analizy rankingu www.top.bigmir.net (Wykres 14), językiem ukraińskim posługuje się 13,20\% stron internetowych, dwujęzyczne są 28,8\%, a w języku rosyjskim $58 \%$. Według danych www.top.i.ua $28 \%$ stron internetowych posługuje się językiem ukraińskim, 20\% stron są dwujęzyczne, a 52\% posługują się językiem rosyjskim. Ranking liveinternet.ru wskazuje, że ukraińskojęzyczne strony internetowe stanowią 14\%, dwujęzyczne 24,8\%, a rosyjskojęzyczne 61,2\%. Ukraińskojęzyczne strony dominują głównie na stronach związanych z państwem, oświatą, literaturą, w innych strefach tematycznych dominuje język rosyjski. Ponadto, język rosyjski dominuje na stronach społecznościowych, jednak udział języka ukraińskiego w ukraińskim segmencie Facebooka w ciągu ostatnich dwóch lat nieznacznie wzróst i wynosi 43\% („Стан української мови: Щорічний моніторинг: Російська домінує в медіа та сфері послуг, українська - в освіті й кінопрокаті", 2016). Роpularność języka rosyjskiego dominuje w ukraińskim internecie. Ukraińskojęzyczni konsumenci często wolą w internecie język ukraiński bądź wykorzystują strony dwujęzyczne, z kolei ludność rosyjskojęzyczna korzysta głównie ze stron w języku rosyjskim. 
Z badań konsultingowej kompanii Gemius przeprowadzonych w styczniu 2016 roku wynika, że Ukraińcy najczęściej odwiedzają 527 stron internetowych. Wszystkie strony umownie można podzielić na 8 grup: portale społecznościowe, Soft i CMS, strony struktur administracji państwowej, media, handel, rozrywka i czas wolny, pomoc i dobre rady, wyszukiwarki i portale. Jak wskazują dane statystyczne, Ukraińcy korzystają z internetu w celu uzyskania informacji z mediów, zakupów, rozrywki (kino i muzyka), wyszukiwania informacji, komunikacji, dla uzyskania niezbędnych programów. W tych umownie określonych segmentach stopień posługiwania się stronami ukraińskojęzycznymi jest różny, często Ukraińcy odwiedzają nieukraińskie strony internetowe w celu uzyskania niezbędnej pomocy lub produktu („Українська мова в інтернеті”, 2016).

\section{JĘZYK UKRAIŃSKI NA SZCZEBLU FORMALNOURZĘDOWYM}

Ciekawie wyglądają statystyki dotyczące posługiwania się językiem ukraińskim w administracji obwodowej po 2014 roku (Ryc. 1). W czasie rozmowy telefonicznej w języku ukraińskim większość osób w centralnej i zachodniej części Ukrainy udzieliła odpowiedzi w języku ukraińskim, wśród wschodnich regionów warto odznaczyć obwód charkowski, który do rewolucji godności uważany był za rosyjskojęzyczny. W obwodach ługańskim, donieckim (z wyjątkiem terenów objętych wojną) oraz w obwodzie dnieprowskim, chersońskim i mikołajewskim po usłyszeniu pytania w języku ukraińskim osoby udzielające odpowiedzi przeszły z języka rosyjskiego na ukraiński, i tylko w dwóch obwodach Ukrainy,

Ryc. 1. Odpowiedzi w języku ukraińskim w sekretariacie gubernatorów ukraińskich obwodów

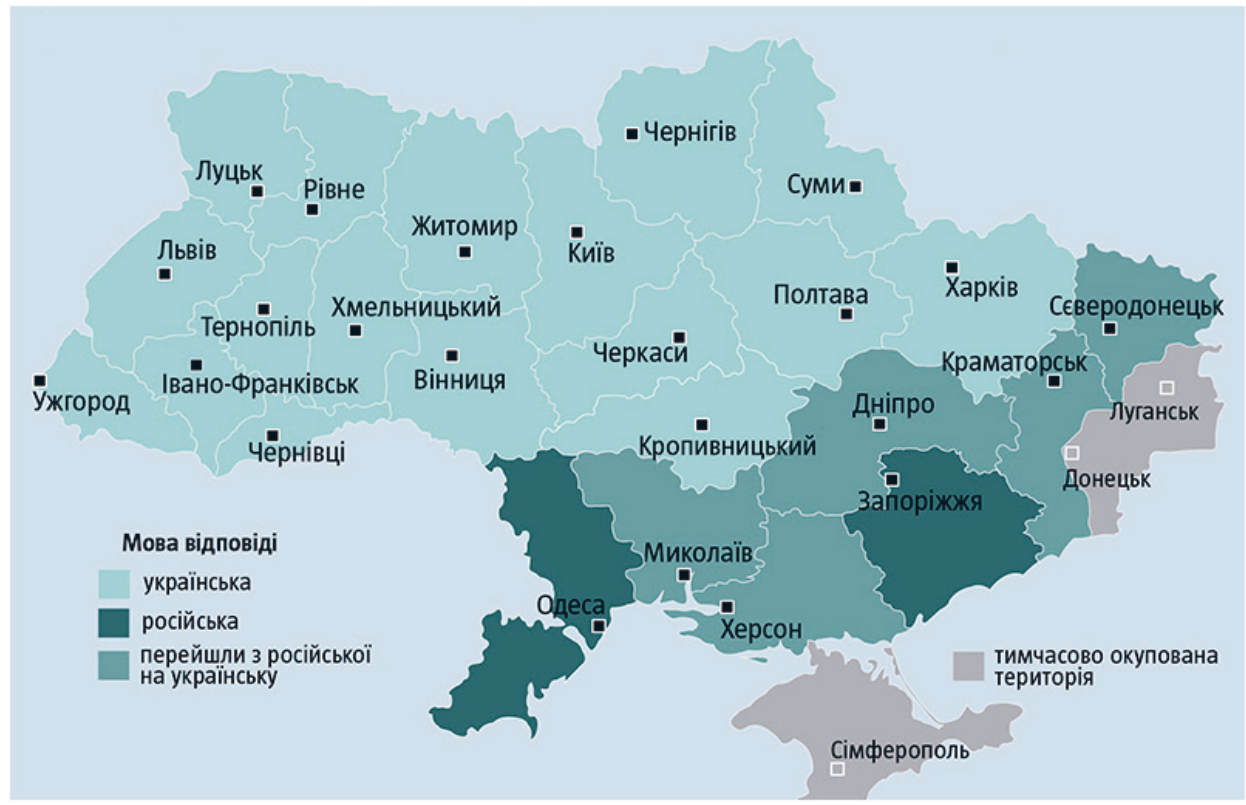

Źródło: Подоляк, 2017. 
zaporoskim i odeskim, na pytanie w języku ukraińskim udzielono odpowiedzi w języku rosyjskim. Taka sytuacja świadczy o tym, że w społeczeństwie ukraińskim po rozpoczęciu działań wojennych w Donbasie znacznie się zmienił stosunek do postrzegania własnej tożsamości i języka.

W roku 2015-2016 liczba uczniów, którzy uzyskują wykształcenie w języku ukraińskim sięgnęła 89,5\%. Liczba uczniów w różnych regionach znacznie się różni. Według danych statystycznych język ukraiński jako główny język nauczania dominuje w obwodzie rówieńskim (100\%), połtawskim (95,7\%), Kijowie (94,7\%) znacznie mniej popularny ukraiński jest w obwodzie charkowskim (65,4\%), odeskim (47,6\%), tugańskim (49,7\%), donieckim (35,7\%). Ogólny wskaźnik dla Ukrainy stanowi 84,9\% („Стан української мови: Щорічний моніторинг", 2016). Należy odnotować, że realna sytuacja w ukraińskich szkołach znacznie się różni od statystyk. W wielu ukraińskich szkołach, szczególnie na wschodzie kraju i na południu, godziny wychowawcze, a czasem i proces nauczania de facto jest w języku rosyjskim. Jeszcze gorsza jest sytuacja w przedszkolach.

Problemem w organach władzy jest niedostateczna znajomość języka ukraińskiego i co z tego wynika - używanie języka rosyjskiego w organach administracji państwowej. Dzisiaj językiem władzy jest przeważnie język rosyjski, brak odpowiedniej kontroli za wykonaniem Ustawy o służbie w organach władzy publicznej, powoduje to, że nikt nie ponosi odpowiedzialności za niewykonanie ustawy („Нардеп Денисенко”, 2016).

\section{JĘZYK UKRAIŃSKI NA SZCZEBLU SYMBOLICZNYM I TOŻSAMOŚCIOWYM}

Przed okupacją Donbasu głównymi obszarami funkcjonowania języka ukraińskiego na wschodzie kraju były edukacja, administracja, częściowo sądownictwo. Ponadto, język ukraiński można było spotkać w kinie i reklamie. Ukraińskie kanały telewizyjne, stacje radiowe także były obecne w Donbasie. W ciągu pierwszych 15 miesięcy okupacji język ukraiński został usunięty ze wszystkich sfer życia publicznego, co potwierdza analiza stanu języka ukraińskiego na terenach okupowanych. Wraz ze stopniową utratą terenów na wschodzie kraju, Ukraina straciła możliwość wpływu na stan i sytuację języka ukraińskiego na terenach okupowanych. Ze względu na rosyjską tożsamość Donieckiej Republiki Ludowej (DRL) i Ługańskiej Republiki Ludowej (LRL) rozpoczęła się intensywna rusyfikacja tych terenów.

W wielu miejscowościach Ukrainy wschodniej i południowej dokumentacja biurowa w urzędach państwowych i samorządach jeszcze do okupacji Donbasu często była prowadzona w języku rosyjskim. Po rozpętaniu wojny w Donbasie język ukraiński szybko wyeliminowano z tych organów władzy państwowej. W dniu 23 grudnia 2014 roku za język administracji w DRL i LRL oficjalnie uznano język rosyjski. Edukacja na okupowanych terenach także jest w języku rosyjskim, a język ukraiński został zakazany. W 2014-2015 roku proces nauczania w języku ukraińskim został całkowicie przeniesiony na język rosyjski, zlikwidowano klasy z ukraińskim językiem nauczania, zmniejszono liczbę godzin jego nauczania. Formalnie likwidacja klas z ukraińskim językiem nauczania odbywała się za zgodą rodziców na podstawie ich podań, aby rusyfikować proces nauczania. Bardzo często rodziców zmuszano do pisania takich podań poprzez szantaż. Całkowicie wyeliminować język ukraiński z procesu kształcenia władzom samozwańczych republik się nie udało. Zajęcia z języka ukraińskiego w wielu szkołach z obowiązkowych przeniesiono w status fakultatywnych i ograniczono do jednej godziny w tygodniu. 
Latem 2014 roku na terenach okupowanych zaprzestały nadawać ukraińskie kanały telewizyjne. Język ukraiński został całkowicie wyeliminowany z miejscowych kanałów telewizyjnych, które nadają w języku rosyjskim. Dostawców usług internetowych zmuszają do blokowania ukraińskich stron internetowych. Na terenach okupowanych nie ma żadnych czasopism i gazet wydawanych w języku ukraińskim. Jednocześnie naoczni świadkowie świadczą, że w pojedynczych księgarniach Doniecka można kupić pojedyncze książki w języku ukraińskim ( „Українська мова на Донбасі”, 2015).

Używanie języka ukraińskiego na ulicach Doniecka może być niebezpieczne. Jak zaznaczył na swojej stronie facebookowej analityk grupy "Sprzeciw informacyjny" Dmytro Tymczuk, w lipcu 2015 roku Ministerstwo Bezpieczeństwa Narodowego DRL rozpoczęło aktywne przeciwdziałania „aktom nieposłuszeństwa obywatelskiego" w postaci publicznych przejawów proukraińskiej pozycji poszczególnymi obywatelami (graffiti, publiczne słuchanie ukraińskiej muzyki w transporcie i na ulicy, produkcja i rozpowszechnianie ulotek o proukraińskiej treści) i wzywa obywateli republiki, by donosili o takich przejawach niepokory do Ministerstwa Bezpieczeństwa Narodowego (Tymchuk, 2015).

Lata okupacji negatywnie odbiły się na sytuacji języka ukraińskiego na terenach okupowanych. Język ukraiński został wyeliminowany ze wszystkich sfer życia publicznego. Proces rusyfikacji w Donbasie przedstawiono jako „proces obiektywny i naturalny”. W 2016 roku na liście przedmiotów szkolnych nie było języka ukraińskiego, a dzieci na terenach okupowanych nauczano „języków narodów Donbasu” i "literatury narodów Donbasu”. Sytuacja na Krymie jest bardzo podobna, języka ukraińskiego lub krymskotatarskiego można uczyć się dodatkowo za zgodą rodziców („Українська мова в Криму”. 2017). W republikańskiej konstytucji język ukraiński uznawany jest za język państwowy wraz z rosyjskim i krymskotatarskim. Jednak w rzeczywistości prawa krymskich Ukraińców przestrzegane są tylko na papierze. Na portalach społecznościowych często można znaleźć informacje o "rosyjskich porządkach" w szkołach republiki. Na Krymie nauczyciele języka ukraińskiego są zmuszani do przekwalifikowania w celu nauczania języka i literatury rosyjskiej („Стан української мови: Щорічний моніторинг", 2016).

\section{WNIOSKI}

Rozwiązanie problemu językowego jest ważnym zadaniem dla ukraińskiej władzy. W realiach wojny w Donbasie i zajęcia Krymu problem językowy stoi bardzo ostro. Ukraina powinna udoskonalić ustawodawstwo oraz wypracować strategie rozwoju, wspierania i popularyzacji języka ukraińskiego. Jednocześnie należy jasno uświadomić, że kampania odrodzenia języka ukraińskiego powinna być skierowana przede wszystkim do dzieci i młodzieży. Ukrainizacja starszego pokolenia jest mało efektywna i nie jest konieczna. Ważne jest to, aby starsze pokolenie uświadomiło, jak ważne znaczenie ma język ukraiński dla bytu państwa ukraińskiego i popierało jego używanie i naukę w swoich rodzinach. Bez wsparcia państwa proces popularyzacji języka ukraińskiego jest niemożliwy. Jak wynika z powyższej analizy proces ukrainizacji należy zaczynać od internetu, który stal się nieodłączną częścią życia młodszego pokolenia. Obecnie ukrainizacja internetu odbywa się powoli, a konkurencję w tym segmencie wciąż stanowi język rosyjski, poniekąd i angielski. Szczególną uwagę należy poświęcić Wikipedii, która jest kopalnią wiedzy, jednak 
jej ukraińska wersja jest słabo rozwinięta, a więc poszukując informacji, chcąc nie chcąc sięgamy do stron w językach obcych.

Ważne znaczenie w procesie popularyzacji języka ukraińskiego ma wydawanie książek w języku ukraińskim. Niestety książki na Ukrainie są drogie, co powoduje stosunkowo niskie nimi zainteresowanie. Wyjściem z tej sytuacji może być cyfryzacja. Ponadto, państwo powinno zwalczać nielegalną sprzedaż rosyjskojęzycznych książek które są dostępne w internecie. Proces ten powinien odbywać się stopniowo, najpierw należy ograniczyć sprzedaż książek w języku rosyjskim i stopniowo zmniejszać ich obecność na ukraińskim rynku. Przy tym należy racjonalnie podchodzić do tej kwestii, gdyż warto zastanowić się, czy jest potrzeba, by tłumaczyć rosyjską klasykę. Jest to kwestia dyskusyjna. Audio książki i książki elektroniczne mogą się stać istotnym instrumentem popularyzacji czytania, które w ostatnich latach nie cieszy się dużą popularnością. Ważne znaczenie w procesie wzmocnienia języka ukraińskiego ma radio i telewizja. Z danych statystycznych wynika, że $w$ ostatnich latach zmiany idą $w$ dobrym kierunku, jednak są one niewielkie. Język rosyjski wciąż dominuje $w$ mediach, prasie, radiu i telewizji. W ostatnich latach pojawiło się wiele inicjatyw społecznych, które popularyzują język ukraiński i zachęcają do jego używania w życiu codziennym. Ważne jest także przyjęcie odpowiednich ustaw, które precyzyjnie określą status języka ukraińskiego i języków mniejszości narodowych. Jest to proces trudny.

\section{BIBLIOGRAFIA}

GFK Ukraine: Рейтинг радіостанцій України. (2015, czerwiec 17). Pobrano 17 czerwca 2017, z https://mresearcher.com/2015/06/gfk-ukraine-rejting-radiostancij-ukraïni.html

Olszański, T. (2012). Problem językowy na Ukrainie: Próba nowego spojrzenia. Pobrano 17 czerwca 2017, z https://www.osw.waw.pl/sites/default/files/prace_40_0.pdf

Tymchuk, D. (2015, lipiec 8). Оперативные данные группы „Информационное Сопротивление". Pobrano 20 czerwca 2018, z https://www.facebook.com/dmitry.tymchuk/posts/7 20342361427755 ?pnref=story

Voytyuk, O. (2017). Tatarzy Krymscy: Sytuacja narodu w warunkach zmieniających się państwowości. Białystok: Instytut Badań nad Dziedzictwem Kulturowym Europy.

В Україні оприлюднили список із 500 заборонених російських фільмів і серіалів. (2016, listopad 30). Pobrano 17 czerwca 2017, z http://tyzhden.ua/News/179749

В усіх типах медій споживачі віддають перевагу продуктам українською мовою (опитування). (2017, sierpień 17). Pobrano 17 czerwca 2017, z http://language-policy.info/2017/08/v-usih-typah-medij-spozhyvachi-viddayut-perevahu-produktam-ukrajinskoyu-movoyuopytuvannya/\#more-4411

Ідентичність громадян України в нових умовах: Стан, тенденції, регіональні особливості. (2016). Національна безпека і оборона, 2016(3-4).

Лесюк, Я., \& Шаповал, В. (2017, wrzesień 18). Державна мова: право чи обов'язок. Роbrano 20 czerwca 2018, z http://glavcom.ua/publications/derzhavna-mova-pravo-chiobovyazok-437792.html

Лиманов, Р. (1991). Возродить язык, чтобы возродить нацию. Авдет, 1991(14(25)).

Мовний баланс України. (2017, wrzesień 10). Pobrano z http://uabooks.info/ua/book_market/analytics/?pid=2386 
Нардеп Денисенко назвав 5 кроків для відродження української мови. (2016, marzec 29). Gazeta.ua. Pobrano 20 czerwca 2018, z https://gazeta.ua/articles/sogodennya/_nardepdenisenko-nazvav-5-krokiv-dlya-vidrodzhennya-ukrayinskoyi-movi/688506

Огляд ринку: Книговидання. (2017, marzec 29). Pobrano 18 września 2017, z https://msb. aval.ua/news/?id=26190

Подоляк, І. (2017, тај 7). Мовне божевілля. Тиждень.иа. Pobrano 20 czerwca 2018, z http://tyzhden.ua/Columns/50/191480

Про внесення змін до деяких законів України щодо частки музичних творів державною мовою у програмах телерадіоорганізацій. (b.d.). Pobrano 3 października 2017, z http:// zakon5.rada.gov.ua/laws/show/1421-19

Про внесення зміни до статті 151 Закону України „Про кінематографію”. (2016, kwiecień 21). Голос України. Pobrano 20 czerwca 2018, z http://www.golos.com.ua/article/267638

Російська мова домінує в медіа та сфері послуг, українська - в освіті й кінопрокаті. (2016, listopad 8). Pobrano 20 czerwca 2018, z http://dobrovol.org/article/347/

"Свати" ще не заборонили, але можуть: чому і за що. (2017, listopad 24). Pobrano 20 czerwca 2018, z https://www.radiosvoboda.org/a/28875301.html

Спільна ідентичність громадян України. (2007). Національна безпека і оборона, 2007(9).

Стан української мови: щорічний моніторинг. (2016, listopad 8). Тиждень.иа. Pobrano 20 czerwca 2018, z http://tyzhden.ua/Infographics/177977

Стан української мови: Щорічний моніторинг: Російська домінує в медіа та сфері послуг, українська - в освіті й кінопрокаті. (2016, listopad 8). Pobrano 20 czerwca 2018, z http:// texty.org.ua/pg/article/Oximets/read/72173/Stan_ukrajinskoji_movy_Shhorichnyj_monitoryng_Rosijska_dominuje

Українська мова в інтернеті: Торгівля, нерухомість, розваги - тут все російською (інфографіка). (2016, grudzień 12). Pobrano 20 czerwca 2018, z http://texty.org.ua/pg/article/editorial/read/73060/Ukrajinska_mova_v_interneti_Torgivla_neruhomist_rozvagy

Українська мова в Криму: „Ритуальне” знищення. (2017, lipiec 20). Газета Експрес. Pobrano 20 czerwca 2018, z http://expres.ua/news/2017/07/20/253156-ukrayinska-mova-krymu-rytualne-znyshchennya

Українська мова на Донбасі: Рік під окупацією. (2015, lipiec 9). Pobrano 20 czerwca 2018, z http://galinfo.com.ua/articles/ukrainska_mova_na_donbasi_rik_pid_okupatsiieyu_199057.html

\section{BIBLIOGRAPHY (TRANSLITERATION)}

GFK Ukraine: Reĭtynh radiostantsiĭ Ukraïny. (2015, June 17). Retrieved June 17, 2017, from https://mresearcher.com/2015/06/gfk-ukraine-rejting-radiostancij-ukraïni.html

Identychnist' hromadian Ukraïny $v$ novykh umovakh: Stan, tendentsiï, rehional'ni osoblyvosti. (2016). Natsional'na bezpeka i oborona, 2016(3-4).

Lesiuk, I., \& Shapoval, V. (2017, September 18). Derzhavna mova: pravo chy obov'iazok. Retrieved June 20, 2018, from http://glavcom.ua/publications/derzhavna-mova-pravochi-obovyazok-437792.html

Limanov, R. (1991). Vozrodit' iazyk, chtoby vozrodit' natsiiu. Avdet, 1991(14(25)).

Movnyı̆ balans Ukraïny. (2017, September 10). Retrieved from http://uabooks.info/ua/ book_market/analytics/?pid=2386 
Nardep Denysenko nazvav 5 krokiv dlia vidrodzhennia ukraïns'koï movy. (2016, March 29). Gazeta.ua. Retrieved June 20, 2018, from https://gazeta.ua/articles/sogodennya/_nardep-denisenko-nazvav-5-krokiv-dlya-vidrodzhennya-ukrayinskoyi-movi/688506

Ohliad rynku: Knyhovydannia. (2017, March 29). Retrieved September 18, 2017, from https://msb.aval.ua/news/?id=26190

Olszański, T. (2012). Problem językowy na Ukrainie: Próba nowego spojrzenia. Retrieved June 17, 2017, from https://www.osw.waw.pl/sites/default/files/prace_40_0.pdf

Podoliak, I. (2017, May 7). Movne bozhevillia. Tyzhden'.ua. Retrieved June 20, 2018, from http://tyzhden.ua/Columns/50/191480

Pro vnesennia zmin do deiakykh zakoniv Ukraïny shchodo chastky muzychnykh tvoriv derzhavnoiu movoiu u prohramakh teleradioorhanizatsĭ. (n.d.). Retrieved October 3, 2017, from http://zakon5.rada.gov.ua/laws/show/1421-19

Pro vnesennia zminy do statti 151 Zakonu Ukraïny "Pro kinematohrafiiu”. (2016, April 21). Holos Ukraïny. Retrieved June 20, 2018, from http://www.golos.com.ua/article/267638

Rosiǐs'ka mova dominuie v media ta sferi posluh, ukraïns'ka - v osviti ı̌ kinoprokati. (2016, November 8). Retrieved June 20, 2018, from http://dobrovol.org/article/347/

Spil'na identychnist' hromadian Ukraïny. (2007). Natsional'na bezpeka i oborona, 2007(9).

Stan ukraïns'koï movy: Shchorichnyı̆ monitorynh. (2016, November 8). Tyzhden'.ua. Retrieved June 20, 2018, from http://tyzhden.ua/Infographics/177977

Stan ukraïns'koï movy: Shchorichnyı̆ monitorynh: Rosiüs'ka dominuie v media ta sferi posluh, ukraïns'ka - v osviti ì kinoprokati. (2016, November 8). Retrieved June 20, 2018, from http://texty.org.ua/pg/article/Oximets/read/72173/Stan_ukrajinskoji_movy_Shhorichnyj_monitoryng_Rosijska_dominuje

"Svaty" shche ne zaboronyly, ale mozhut': chomu i za shcho. (2017, November 24). Retrieved June 20, 2018, from https://www.radiosvoboda.org/a/28875301.html

Tymchuk, D. (2015, July 8). Operativnye dannye gruppy "Informatsionnoe Soprotivlenie". Retrieved from https://www.facebook.com/dmitry.tymchuk/posts/720342361427755? pnref=story

Ukraïns'ka mova na Donbasi: Rik pid okupatsiieiu. (2015, July 9). Retrieved June 20, 2018, from http://galinfo.com.ua/articles/ukrainska_mova_na_donbasi_rik_pid_okupatsiieyu_199057.html

Ukraïns'ka mova v interneti: Torhivlia, nerukhomist', rozvahy - tut vse rosiǐs'koiu (infohrafika). (2016, December 12). Retrieved June 20, 2018, from http://texty.org.ua/pg/article/editorial/read/73060/Ukrajinska_mova_v_interneti_Torgivla_neruhomist_rozvagy

Ukraïns'ka mova v Krymu: „Rytual'ne” znyshchennia. (2017, July 20). Hazeta Ekspres. Retrieved June 20, 2018, from http://expres.ua/news/2017/07/20/253156-ukrayinskamova-krymu-rytualne-znyshchennya

V Ukraïni opryliudnyly spysok iz 500 zaboronenykh rosiľs'kykh fil'miv i serialiv. (2016, November 30). Retrieved June 17, 2017, from http://tyzhden.ua/News/179749

V usikh typakh medii spozhyvachi viddaiut' perevahu produktam ukraïns'koiu movoiu (opytuvannia). (2017, August 17). Retrieved June 17, 2017, from http://language-policy.info/2017/08/v-usih-typah-medij-spozhyvachi-viddayut-perevahu-produktam-ukrajinskoyu-movoyu-opytuvannya/\#more-4411

Voytyuk, O. (2017). Tatarzy Krymscy: Sytuacja narodu w warunkach zmieniających sie państwowości. Białystok: Instytut Badań nad Dziedzictwem Kulturowym Europy. 